\title{
Epidemiological and clinical characteristic of Hymenolepis diminuta infection - review of current literature
}

\author{
Patrycja Kapczuk ${ }^{\mathrm{A}}$, Dariusz Chlubek ${ }^{\mathrm{B}}$, Irena Baranowska-Bosiacka ${ }^{\mathrm{C}} \bowtie$ \\ Pomeranian Medical University in Szczecin, Department of Biochemistry and Medical Chemistry, Powstańców Wlkp. 72, 70-111 Szczecin, Poland \\ A ORCID: 0000-0002-2766-7783; ${ }^{\text {B }}$ ORCID: 0000-0003-4497-4395; C ORCID: 0000-0001-9187-8895 \\ $\triangle$ patrycja.kapczuk@pum.edu.pl
}

\begin{abstract}
Hymenolepis diminuta (rat tapeworm) is widespread worldwide, though in comparison to $H$. nana it is less frequent in humans (accidental host). The definite hosts, as well as the natural reservoir of $H$. diminuta, are small rodents. Literature on the subject reports that the predisposition to infestation with this tapeworm mainly concerns small children and adults from a poor socioeconomic background. The epidemiological data presented
\end{abstract}

in this article provide the lastest scientific information on the prevalence of this parasite, the course of hymenolepiasis, as well as the treatment method. Owing to the low prevalence of hymenolepiasis in humans, the diagnosis, analysis and description of the course of the disease in humans provides new and crucial information on $H$. diminuta infection.

Keywords: hymenolepiasis; tapeworm; epidemiology.

\section{INTRODUCTION}

The rat tapeworm Hymenolepis diminuta (Cestoda) is a common intestinal parasite of small rodents, such as mice and rats. It is common in temperate and tropical climate zones. Even though it is a rat parasite, there are reported cases of infections in people as accidental hosts $[1,2,3,4,5,6]$. Owing to the simple lifecycle of Hymenolepis diminuta, it is used as a model parasite in studies on the parasite-host system. Experimental studies on the effect of $H$. diminuta infestation on a host's organism mostly use the rat model. The mouse model is not as applicable due to the overly increased activity of the immune system in primary and secondary infections $[7,8]$. It is proven that the tapeworm is not excreted from the body of a rat infected with a small number of parasites (10-20). Therefore, $H$. diminuta may live as long as its host (to 14 years) [6, 9, 10, 11, 12,13].

\section{STRUCTURE AND LIFECYCLE OF H. DIMINUTA RUDOLPHI, 1819}

The structure of $H$. diminuta comprises: the scolex (head), the neck, which is where new segments of tapeworm are present, and proglottids (segments) forming the strobila. The strobila of an adult tapeworm can be as long as $20-60 \mathrm{~cm}$ and have the thickness of 3-5 $\mathrm{mm}$. The length of $H$. diminuta is determined by the extent of infection (the so-called crowding effect). There are reports of $90 \mathrm{~cm}$ long specimens. The parasite has $800-1000$ proglottids of $3.5 \mathrm{~mm}$ in width and 0.76 in length Figure $1[8,14,15,16]$.

Since the tapeworm has both male and female reproductive organs, each segment contains a complete set of internal organs. The terminal segments (uterine segments) are the
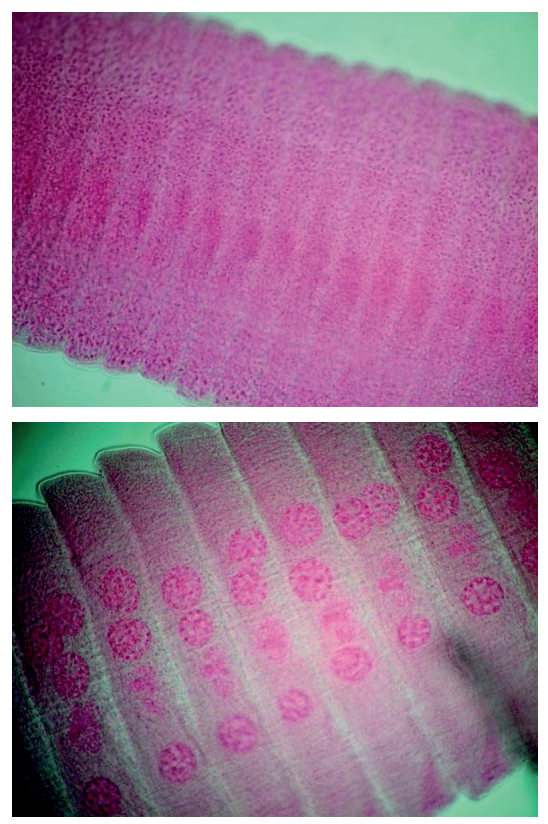

FIGURE 1. Proglottids of rat tapeworm (Hymenolepis diminuta): $\mathrm{A}-$ at $10 \mathrm{x}$ magnification (original photography); $B$ - filled at $10 \mathrm{x}$ magnification (original photography)

place of maturation of individual organs at a given time interval, with male organs maturing as first producing spermatozoa, followed by maturation of the female organs - ovaries. The scolex does not have hooks, but is equipped with 4 suckers allowing attachment to the host's intestinal wall - Figure $2[17,18]$.

Similarly to other tapeworms, $H$. diminuta does not have a circulatory system, nor a digestive system, and absorption of small intestine matter rich in nutrients (the host's digestive milk) occurs through the whole body surface through the 


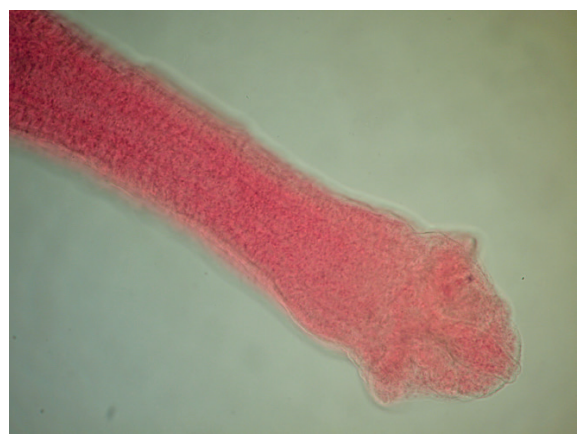

FIGURE 2. Scolex and neck of rat tapeworm (Hymenolepis diminuta) at $10 \mathrm{x}$ magnification (original photography)

cuticle. The cuticle has a vital role in the process of excreting metabolic products, it secretes substances covering the body of the parasite to protect it from the action of digestive enzymes produced by the host. Below the cuticle is a dermato-muscular epithelium - tegument. The muscular system of this parasite is very complex. Underneath the epithelial tissue, the locomotor system is built from myocytes which form a circular layer (located externally), the longitudinal layer (located deeper) and myofibrils. Myocytes are characterised by the presence of cellular organelles including a nucleus, rough endoplasmic reticulum, ribosomes, the Golgi apparatus, mitochondria as well as lipids and glycogen. Myofibrils consist of actin and myosin, responsible for contractility and movement production. Below the layer of muscles are myoblasts and parenchymal cells. Additionally, there are calcareous corpuscles between the parenchyma cells. The nervous system of H. diminuta consists of 2 main nerve trunks extending laterally. The transverse plexus (the central, cerebral ganglion) is located in the head, and the subcutaneous nervous system plexuses extend along the body below the tegument epithelium. The trunks branch in segments, allowing the tapeworm to react to tactile stimulation $[3,17,18,19,20,21,22]$.

The eggs of the parasite are ovoid or slightly oval and 60-85 $\mu \mathrm{m}$ in diameter, with a thick striated external sheath and a thin internal sheath. Additionally, the oncosphere of the egg does not contain polar filaments of the external sheath, but instead contains 6 characteristics centrally located hooks - Figure $3[2,17,23]$.

The lifecycle of $H$. diminuta involves 2 hosts: the intermediate hosts include beetles (Tenebrio and Tribolium), fleas (Ctenocephalides, Xenopsylla, and Pulex), cockroaches and caterpillars, and the definite host - mainly small rodents, most of all rats and mice. Following the arthropods ingesting the tapeworm eggs, the oncospheres penetrate into the host's intestinal wall. The cysticercoid maturation process lasts approx. 10-14 days. Following this, infestation of the definite host occurs following ingestion of the infected intermediate host and the release of mature cysticercoids. In the stomach and intestine of the definite host, the parasite reacts to the chemical signals and penetrates into the intestinal lumen. Then, it attaches to the intestinal mucosa and reaches maturity, about 18-24 days, producing more than 250,000 eggs every day. However, few of them
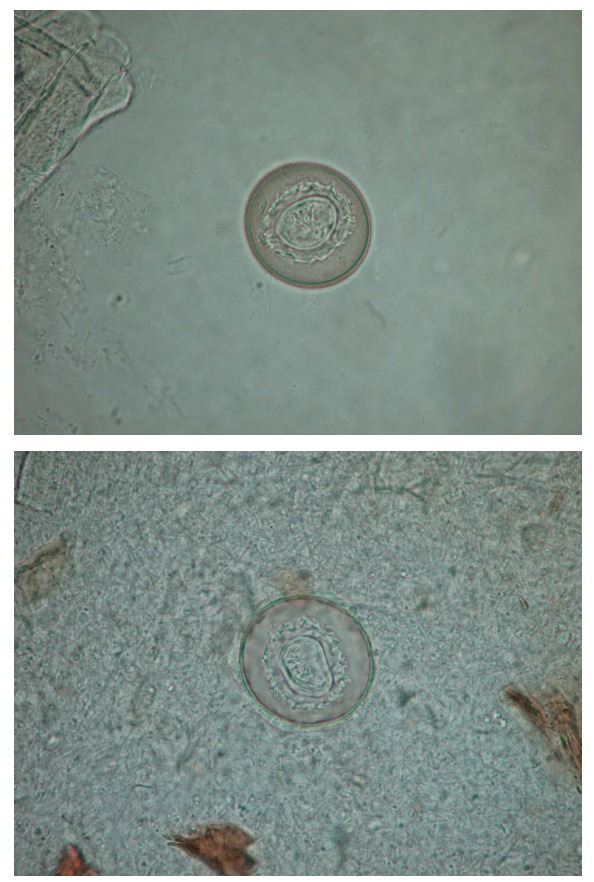

FIGURE 3. Egg of rat tapeworm (Hymenolepis diminuta): A - with 4 visible hooks at $40 \times$ magnification (original photography); B - with 6 visible hooks at $40 \mathrm{x}$ magnification (original photography)

reach full reproductive maturity. Releasing proglottids filled with eggs occurs with defecation by the infected definite host. In the case of people, infestation may take place due to accidental ingestion of food contaminated with insects or their faeces $[2,17,23,24,25,26]$.

\section{EPIDEMIOLOGY}

According to literature on the subject, the predisposition to be infected with intestinal parasite mainly concerns in small children and adults from poor socioeconomic backgrounds. Additional factors increasing the risk of intestinal parasite transmission include variable dietary habits and culinary tastes, and consumption of unwashed food or food of unknown origin. Other factors affecting the occurrence of parasitoses in people are socioeconomic conditions, low personal hygiene, migrations and social status. The difference between reported frequencies of infections between developing and developed countries is distinguishable, being higher most of all in countries with poor living conditions, e.g. lack of sewage system or poor access to drinking water or medicine $[27,28,29,30,31$, $32,33,34,35]$.

Hymenolepiasis particularly affects children, though each age group have seen cases reported. Both in developing and developed countries, the greater likelihood of tapeworm transmission in small children is probably due to yet undeveloped hygiene habits and geophagy, while in developing countries, the risk of parasitosis is higher due to poverty, undernourishment, illiteracy, high population density and low socioeconomic status $[28,30,32,34,36,37,38]$. 
Epidemiological data indicate a constant rise in H. diminuta infections. So far, there have been approx. 500 cases reported worldwide, with the severity of the infection related to the population status in a given country. Infections have been reported in all continents. The reports of worldwide studies of various populations have shown the level of occurrence of H. diminuta in faecal samples is about 0.001-5.5\%. There have been reports of infections in people, in Indonesia, Thailand, the USA, the Democratic Republic of São Tomé and Principe, Italy, Spain, Turkey, Jamaica, Iran, Malaysia, as well as in Poland Table $1[39,40,41,42,43,44,45,46,47,48,49,50,51,52,53,54$ $55,56,57]$.

The first cases of hymenolepiasis in people were reported as early as in 1935 in Thailand and in 1965 in the USA. The latter is the case of a 6-year-old boy from New York (USA), with a confirmed presence of cockroaches and rodents in his home [40, 58]. There have been other cases reported in the USA in the previous century concerning children of both sexes, with the confirmed presence of $H$. diminuta eggs in faeces $(1975,1985$ and 1990) $[42,45,46]$. Almost 100 years ago in India, a cohort study of 8,000 faecal samples revealed 20 cases of hymenolepiasis in people [59]. The 4 most recent cases of hymenolepiasis were reported in a 12-year-old girl in 2008, an 18-year-old youth in 2013, a 10-year-old girl in 2014, and an 11-year-old boy in 2016 [49, 52, 53, 55]. India is marked with a gradually increasing number of infections with rat tapeworm, most likely due to insects being an ingredient of everyday food for millions of people. Entomophagy is common in south-eastern Asia and Mexico. More than 2,000 insect species are considered edible and constitute a source of not only protein but also vitamins and iron [60]. In the last 10 years, the presence of $H$. diminuta eggs in faecal samples has been identified worldwide: a 2-year-old girl in 2011 and a 43-year-old man in 2013 from Selangor (Malaysia), a 20-month-old boy from Turkey in 2015, and in 15-month-old boy from Iran in 2017 [36, 51, 56, 57]. The epidemiological data from Iran also show an increasing trend of reported cases of hymenolepiasis: in 1986 in a 10-year-old boy, in 19725 cases including 4 children aged 6-11, and in 2008 in a 16-month-old girl [39, 61, 62]. In Poland, hymenolepiasis in people is reported sporadically. In the period 1994-2019, there were 6 cases reported: in 1994, 1997, 2001, 2002, 2009 and 2014. The first 5 cases were reported in the annual reports of the Provincial Sanitary and Epidemiological Stations and epidemiological inquiries of the Department of Parasitology of the National Institute of Public Health - National Institute of Hygiene in Warsaw. The most recently reported case was that of a 3-year-old boy in 2014 in Starachowice [53, 63, 64, 65, 66, 67].

\section{CLINICAL MANIFESTATION AND THE COURSE OF HYMENOLEPIASIS}

Since the scolex of $H$. diminuta lacks hooks which could mechanically damage the epithelial tissue of the gastrointestinal tract, the parasite is classified as non-invasive. However, numerous studies show that the metabolites secreted by the parasite may result in disorders of the digestive system of the host (rat) causing excessive production of saliva, inhibition of gastric juice secretion and an increase in the activity of trypsin in duodenal fluid. Furthermore, it was found that the adaptive mechanisms developed by $H$. diminuta deactivate the digestive processes in the host and, at the same time, limit the elimination of the parasite, as well as affect the immunological mechanisms and the activity of antioxidative enzymes, resulting in inflammation [68].

The symptoms of hymenolepiasis in people caused by H. diminuta are non-specific and at times are wrongly diagnosed as other illnesses. Rat tapeworm infections are often asymptomatic. In such cases, the disease shows a self-limiting course, and the incubation period amounts to 7 days. However, literature on the subject reports cases of symptomatic hymenolepiasis manifested in indigestion, nausea, abdominal pain, diarrhoea, fever and irritability. At times the occurrence of the following was reported: irritation, itching around the anus, enteritis, anorexia and allergic reactions - Table $1[38,40,42$, $43,44,45,46,47,48,49,50,51,52,53,54,55,56,57]$.

\section{DIAGNOSTICS}

Modern parasitological diagnostics use a variety of diagnostic methods. As for diagnosing intestinal parasites, a golden standard has yet to be established. Consequently, there is an extremely wide range of methodological approaches. Nonetheless, parasitological diagnostics of $H$. diminuta mainly consists of microscopic inspection of samples. The most frequently used biological material used for the identification of rat tapeworm is faeces. It is vital that the material is sampled before the initiation of treatment or a relatively long time after ceasing (1-3 weeks). The use of antibiotics, laxatives, antidiarrheal and antiparasitic medicine, antacids and contrast media may hinder identification of disperse forms or prevent identification of the parasite in faeces. It is important to collect samples from 3 sources (preferably 3 ) and deliver to the laboratory in special stool sample containers (provided with a scoop). In order to obtain the most reliable result, 3 samples are routinely taken and examined. In case of evidence of the fragments of $H$. diminuta (proglottids), it is recommended that they be delivered to the laboratory in containers with a small amount of water. Most often, identification of tapeworm consists of determining the presence of eggs in a direct faecal smear exam with a saline solution or stained with Lugol's solution - Figure $4[36,39,56,69,70]$.

\section{TREATMENT AND PREVENTION}

Literature on the subject provides few reports concerning the therapeutic procedures of treating hymenolepiasis, therefore clinicians have struggled to establish standards of treatment. Consequently, each reported case is an invaluable source of information and contributes to developing an effective mode 


\begin{tabular}{|c|c|c|c|c|c|c|c|c|c|c|}
\hline 짛 & 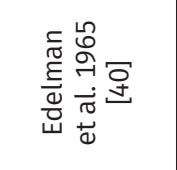 & 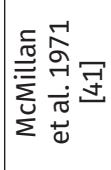 & 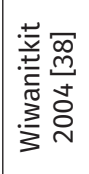 & 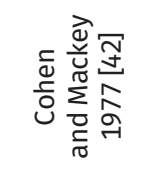 & 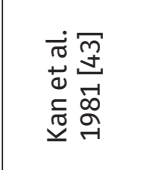 & 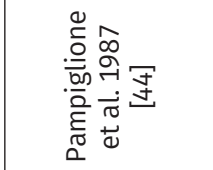 & 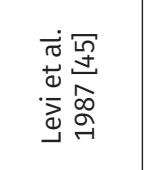 & 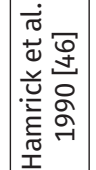 & 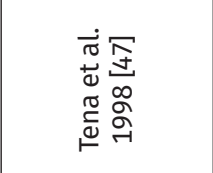 & 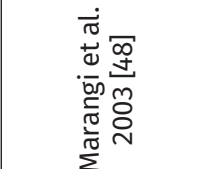 \\
\hline ঙ্ঠ & $\begin{array}{l}\text { ठू } \\
\text { ণे }\end{array}$ & 节 & 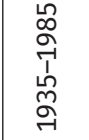 & 占 & 令 & $\begin{array}{l}\text { ळ. } \\
\stackrel{\sigma}{-}\end{array}$ & 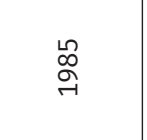 & $\begin{array}{l}\text { S̆ } \\
\text { ने }\end{array}$ & बे & ஜे \\
\hline 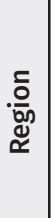 & 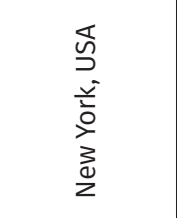 & 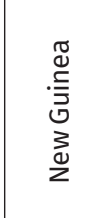 & 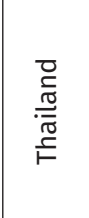 & 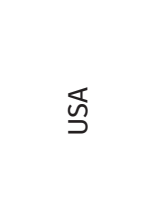 & 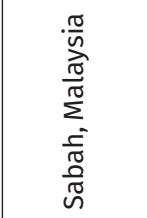 & 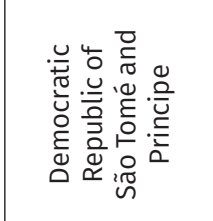 & 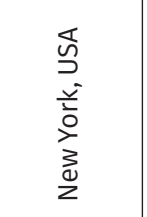 & 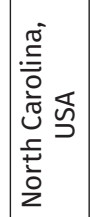 & 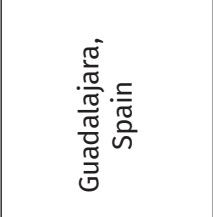 & 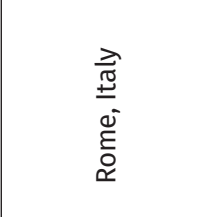 \\
\hline 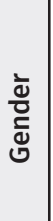 & 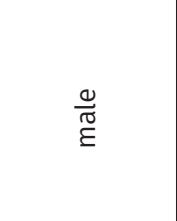 & 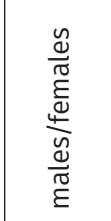 & 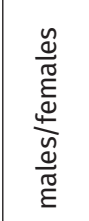 & $\begin{array}{l}\frac{\mathscr{U}}{\pi} \\
\underset{\Psi}{\Psi}\end{array}$ & 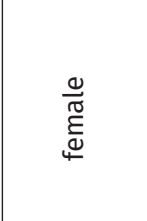 & 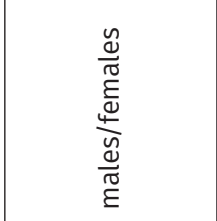 & & 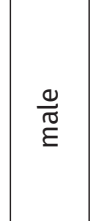 & 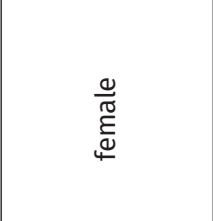 & 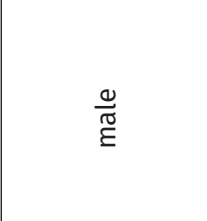 \\
\hline 范 & 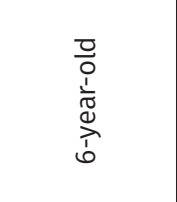 & 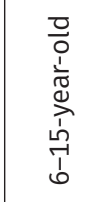 & 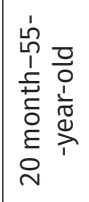 & 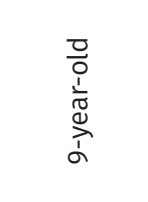 & $\begin{array}{l}\text { 흠 } \\
\text { i } \\
\frac{1}{+} \\
0 \\
\stackrel{0}{0} \\
\dot{\lambda}\end{array}$ & 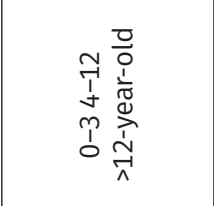 & 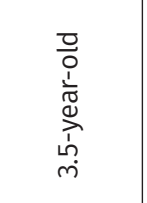 & 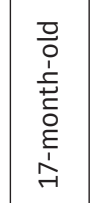 & 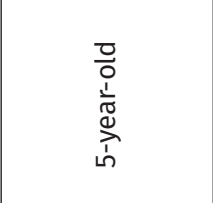 & 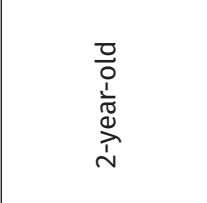 \\
\hline 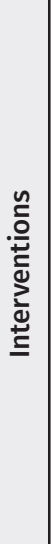 & 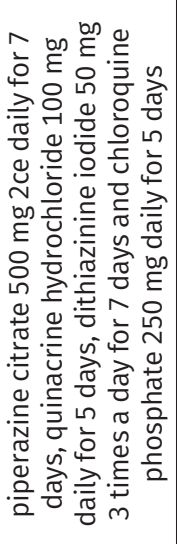 & 1 & 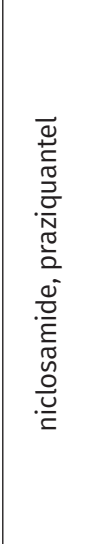 & 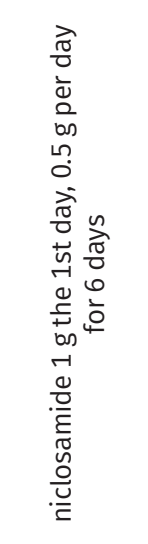 & 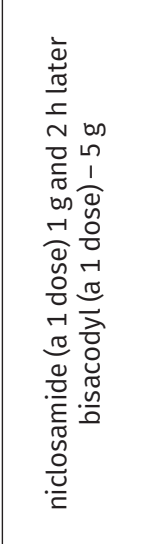 & I & 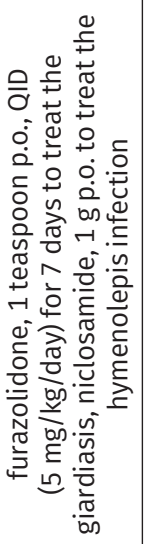 & 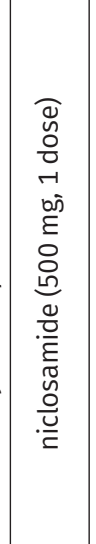 & 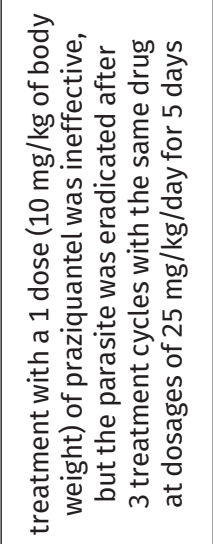 & 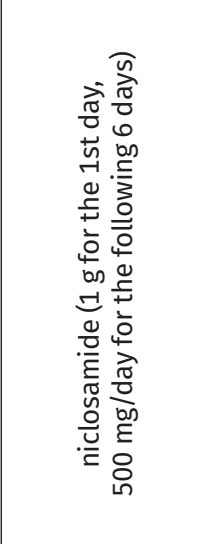 \\
\hline 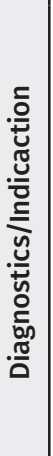 & 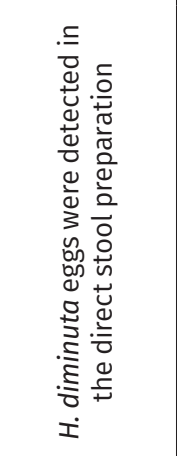 & 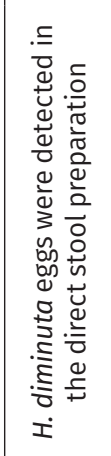 & 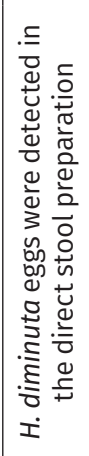 & 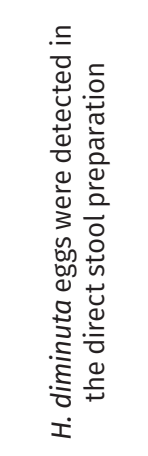 & 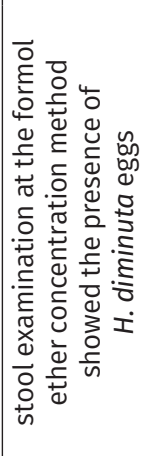 & 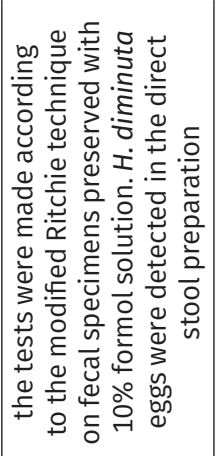 & 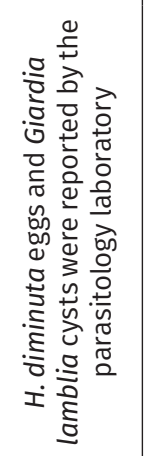 & 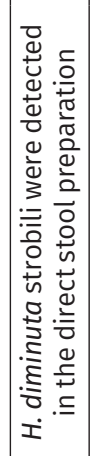 & 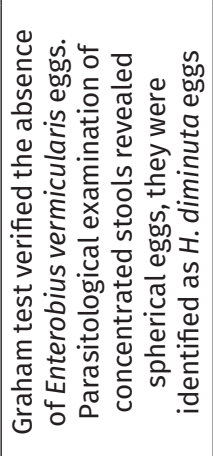 & 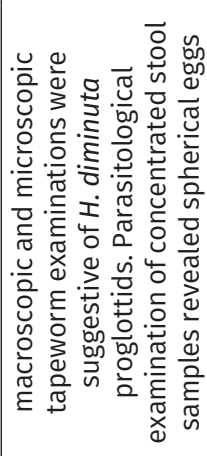 \\
\hline 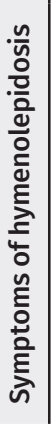 & 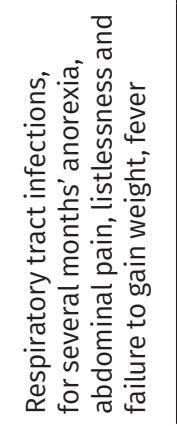 & & 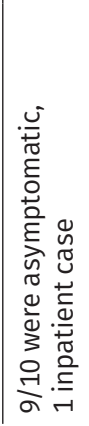 & 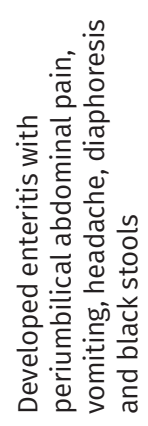 & 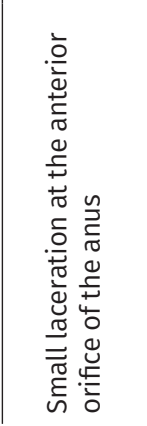 & 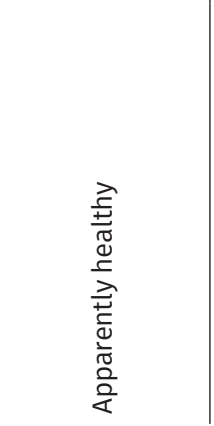 & 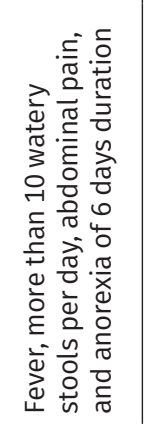 & 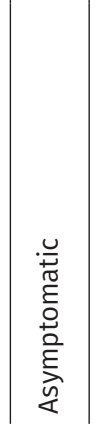 & 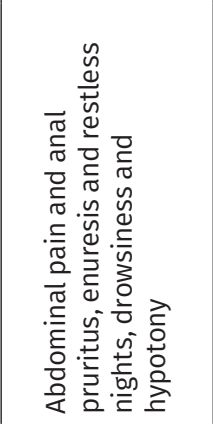 & 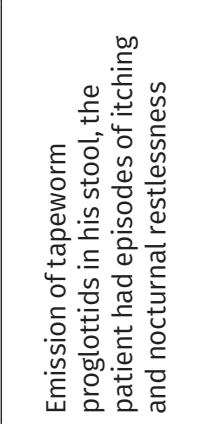 \\
\hline
\end{tabular}




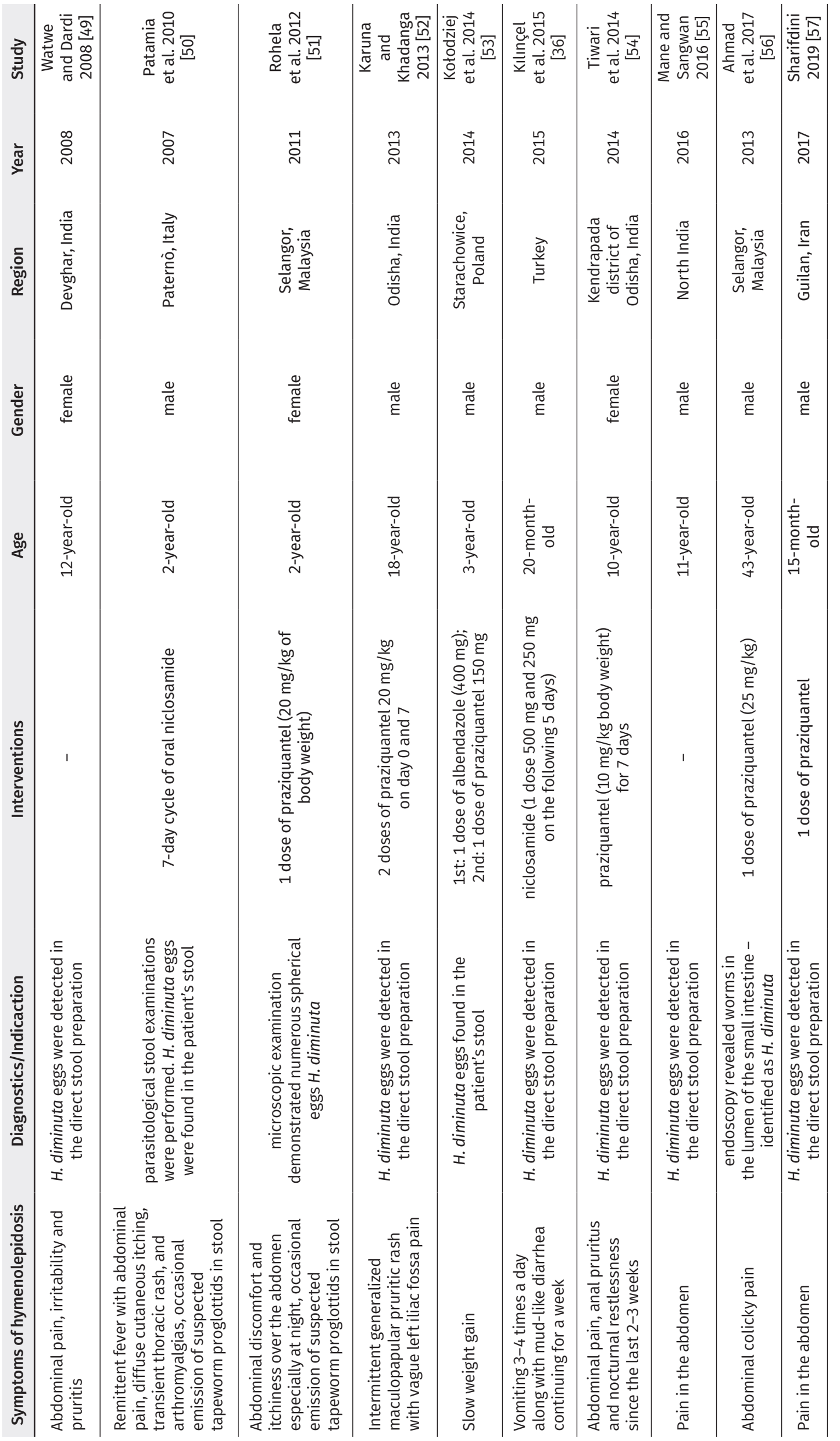



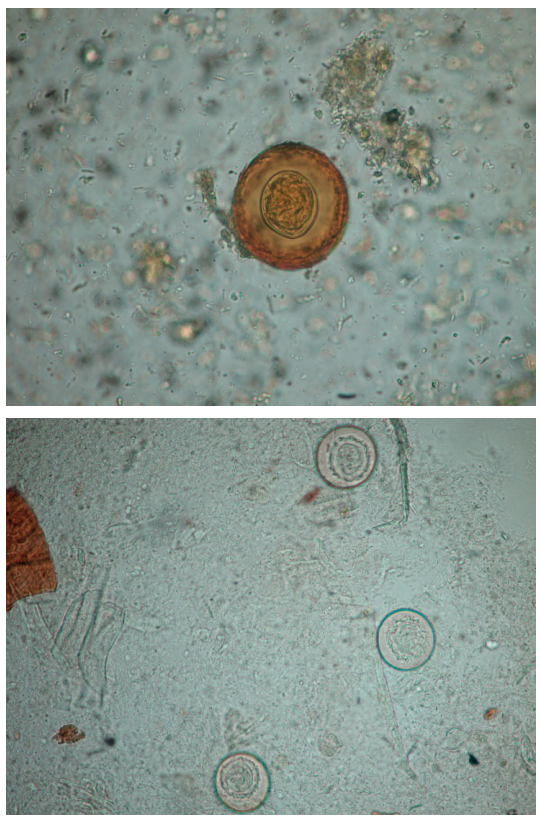

FIGURE 4. Egg of rat tapeworm (Hymenolepsis diminuta) in a stool sample: A - at $40 \times$ magnitude (original photography); B - at $20 \times$ magnitude (original photography)

of treatment. The most frequently used drug of choice in the case of $H$. diminuta infection, both in children as well as adults, is praziquantel and niclosamide (Tab. 1). In most cases, a single dose has proven to be effective. The duration of treatment, however, seems to vary. Literature on the subject indicates the use of other substances and medicines in the treatment of rat tapeworm infection, e.g. piperazine citrate, quinacrine hydrochloride, dithiazanine iodide, chloroquine phosphate, bisacodyl and albendazole [36, 38, 40, 41, 42, 43, 44, 45, 46, 47, $48,49,50,51,52,53,54,55,56,57,71]$.

Human infestation with rat tapeworm can be prevented by means of protecting the food against contamination by rodents and arthropods. Additionally, protective actions should be taken to raise the awareness of threats resulting from ingesting contaminated food and promote appropriate hygiene habits in children.

\section{SUMMARY}

Owing to the low worldwide prevalence of $H$. diminuta, each reported case of infection provides valuable research information with respect to the mechanisms in the parasite-host system. The analysis and description of the disease course provides insight into the treatment and prevention of $H$. diminuta infections. Undoubtedly, epidemiological data concerning hymenolepiasis reflects the worldwide transmission of the parasite and can indicate preventive actions. Knowledge of parasitic infections and resulting health threats, observing hygiene standards and improving sanitary conditions certainly contributes to lowering the prevalence of parasitic diseases.

\section{REFERENCES}

1. Read CP, Kilejian AZ. Circadian migratory behavior of a cestode symbiote in the rat host. J Parasitol 1969;55(3):574-8. doi: 10.2307/3277301.

2. Ishih A, Uchikawa R. Immunoglobulin E and mast cells responses are related to worm biomass but not expulsion of Hymenolepis diminuta during low dose infection in rats. Parasite Immunol 2000;22(11):561-6. doi: 10.1046/j.1365-3024.2000.00330.x.

3. McKay DM, Halton DW, Johnston CF, Shaw C, Fairweather I, Buchanan KD. Hymenolepis diminuta: changes in the levels of certain intestinal regulatory peptides in infected C57 mice. Exp Parasitol 1991;73(1):1526. doi: 10.1016/0014-4894(91)90003-F.

4. Reardon C, Sanchez A, Hogaboam CM, McKay DM. Tapeworm infection reduces epithelial ion transport abnormalities in murine dextran sulfate sodium-induced colitis. Infect Immun 2001;69(7):4417-23. doi: 10.1128/ IAI.69.7.4417-4423.2001.

5. Dwinell MB, Wise RM, Bas P, Oaks JA. Hymenolepis diminuta: Mucosal mastocy tosis and intestinal smooth muscle hypertrophy occur in tapeworm-infected rats. Exp Parasitol 1998;89(1):92-102. doi: 10.1006/ expr.1998.4271.

6. Goswami R, Singh SM, Kataria M, Somvanshi R. Clinicopathological studies on spontaneous Hymenolepis diminuta infection in wild and laboratory rats. Braz J Vet Pathol 2011;4(2):103-11.

7. Hindsbo O, Andreassen J, Ruitenberg J. Immunological and histopathological reactions of the rat against the tapeworm Hymenolepis diminuta and the effects anti-thymocyte serum. Parasite Immunol 1982;4(1):5976. doi: 10.1111/j.1365-3024.1982.tb00420.x.

8. Hopkins CA, Andreassen J. Inhibition of growth of a tapeworm Hymenolepis diminuta in its normal host (rat). Int J Parasitol 1991;21(1):47-55. doi: 10.1016/0020-7519(91)90119-R.

9. Goswami R, Somvanshi R, Singh SM, Singh S. A preliminary survey on incidence of helminthic and protozoal diseases in rats. Indian J Vet Pathol 2009;33(1):90-2.

10. Sadjjadi SM, Massoud J. Helminth parasites of wild rodents in Khuzestan Province, South-West of Iran. J Vet Parasitol 1999;13(1):55-6.

11. Webster JP, Macdonald DW. Parasites of wild brown rats (Rattus norvegicus) on UK farms. Parasitology 1995;111(Pt 3):247-55. doi: 10.1017/ S0031182000081804.

12. Waugh CA, Lindo JF, Foronda P, Angeles-Santana M, Lorenzo-Morales J, Robinson RD. Population distribution and zoonotic potential of gastrointestinal helminths of wild rats R. rattus and Rattus norvegicus from Jamaica. J Parasitol 2006;92(5):1014-8. doi: 10.1645/GE-795R1.1.

13. Firlotte WR. A survey of the parasites of the brown Norway rat. Can J Comp Med Vet Sci 1948;12(7):187-91.

14. Cook RL, Roberts LS. In vivo effects of putative crowding factors on development of Hymenolepis diminuta. J Parasitol 1991;77(1):21-5. doi: $10.2307 / 3282549$.

15. Stradowski M. Effects of inbreeding in Hymenolepis diminuta (Cestoda). Acta Parasitol 1994;39(3):146-9.

16. Zavras ET, Roberts LS. Developmental physiology of cestodes: cyclic nucleotides and the identity of putative crowding factors in Hymenolepis diminuta. J Parasitol 1985;71(1):96-105. doi: 10.2307/3281983.

17. Andreassen J, Bennet-Jenkins EM, Bryant C. Immunology and biochemistry of Hymenolepis diminuta. Adv Parasitol 1999;42:223-75.

18. Pappas PW. Allometric growth of the proglottids and strobila of the tapeworm, Hymenolepis diminuta. J Helminthol 2000;74(3):259-65. doi: 10.1017/S0022149x00000378.

19. Deryło A, editor. Parazytologia i akaroentomologia medyczna. Warszawa: Wydawnictwo Naukowe PWN; 2002.

20. Pawłowski Z, Stefaniak J, editors. Parazytologia kliniczna w ujęciu wielodyscyplinarnym. Warszawa: Wydawnictwo Lekarskie PZWL; 2004.

21. Bogitsh BJ, Carter CE, Oeltmann TN. Chapter 13- Intestinal Tapeworms. In: Bogitsh BJ, Carter CE, Oeltmann TN. Human Parasitology. 4th ed. Amsterdam: Elsevier Inc; 2013. p. 237-49.

22. Schantz PM. Tapeworms (cestodiasis). Gastroenterol Clin North Am 1996;25(3):637-53. doi: 10.1016/s0889-8553(05)70267-3.

23. Malmberg M, Andreassen J, Malmberg G. Hymenolepis diminuta: A comparison between young developing, and small, destrobilated worms in the rat intestine. Z Parasitenkd 1985;71(6):747-57. doi: 10.1007/BF00926800. 
24. Sulima A, Bień J, Savijoki K, Näreaho A, Sałamatin R, Conn DB, et al. Identification of immunogenic proteins of the cysticercoid of Hymenolepis diminuta. Parasit Vectors 2017;10(1):577. doi: 10.1186/s13071-017-2519-4.

25. Pappas PW, Barley AJ. Beetle-to-beetle transmission and dispersal of Hymenolepis diminuta (Cestoda) eggs via the feces of Tenebrio molitor. J Parasitol 1999;85(2):384-5. doi: 10.2307/3285655.

26. Makki MS, Mowlavi G, Shahbazi F, Abai MR, Najafi F, Hosseini-Farash BR, et al. Identification of Hymenolepis diminuta Cysticercoid Larvae in Tribolium castaneum (Coleoptera: Tenebrionidae) Beetles from Iran. J Arthropod Borne Dis 2017;11(2):338-43.

27. Alamir M, Awoke W, Feleke A. Intestinal parasites infection and associated factors among school children in Dagi primary school, Amhara National Regional State, Ethiopia. Health 2013;5(10):1697-701.

28. Banke RO, Omudu EA, Ikenwa DA, Feese IJ. Prevalence of gastro-intestinal parasites in relation to availability of sanitary facilities among schooling children in Makurdi, Nigeria. Anim Res Int 2006;3(2):489-93.

29. Golińska Z, Lach J, Bany J, Chaś J. Występowanie pasożytów jelitowych u dzieci w czterech przedszkolach warszawskich w latach 1994-1996. Prz Epidemiol 1997;51(4):411-6

30. Molina N, Pezzani B, Ciarmela M, Orden A, Rosa D, Apezteguia M, et al. Intestinal parasites and genotypes of Giardia intestinalis in school children from Berisso, Argentina. J Infect Dev Ctries 2011;5(7):527-34

31. Nowak P, Jochymek M, Pietrzyk A. Występowanie pasożytów jelitow ych człowieka w wybranych populacjach na terenie Krakowa w latach 2000-2006 na podstawie badań parazytologicznych kału przeprowadzonych w Laboratorium Parazytologii Wojewódzkiej Stacji Sanitarno-Epidemiologicznej. Wiad Paraztytol 2007;53(4):285-93.

32. Oyeniran OA, Ojurongbe 0, Oladipo EK, Afolabi AY, Ajayi 00, Oloke AA Intestinal Parasitic Infection among Primary School Pupils in Osogbo Nigeria. IOSR-JDMS 2014;13(7):96-101.

33. Shakya B, Shrestha S, Madhikarmi NL, Adhikari R. Intestinal parasitic infection among school children. J Nepal Health Res Counc 2012;10(1):20-3

34. Tandukar S, Sherchan JB, Thapa P, Malla D, Bhandari D, Ghaju R, et al. Intestinal Parasite Infection among School Going Children in Kathmandu Valley. Austin J Pediatr 2015;2(2):1022-5.

35. Wongstitwilairoong B, Srijan A, Serichantalergs O, Fukuda CD, McDaniel P, Bodhidatta L, et al. Intestinal parasitic infection among pre-school children in Sangkhlaburi, Thailand. Am J Trop Med Hyg 2007;76(2):345-50.

36. Kılınçel Ö, Öztürk CE, Gün E, Öksüz Ş, Uzun H, Şahin İ, et al. A rare case of Hymenolepis diminuta infection in a small child. Mikrobiyol Bul 2015;49(1):135-8. doi: 10.5578/mb.8695.

37. Yang D, Zhao W, Zhang Y, Liu A. Prevalence of Hymenolepis nana and H. diminuta from Brown Rats (Rattus norvegicus) in Heilongjiang Province, China. Korean J Parasitol 2017;55(3):351-5. doi: 10.3347/ kjp.2017.55.3.351.

38. Wiwanitkit V. Overview of Hymenolepis diminuta infection among Thai patients. MedGenMed 2004;6(2):7.

39. Mowlavi G, Mobedi I, Mamishi S, Rezaeian M, Haghi Ashtiani MT, Kashi M. Hymenolepis diminuta (Rodolphi, 1819) Infection in a Child from Iran Iranian J Publ Health 2008;37(2):120-2.

40. Edelman MH, Spingarn CL, Nauenberg WG, Gregory C. Hymenolepis diminuta (rat tapeworm) infection in man. Am J Med 1965;38:951-3. doi: 10.1016/0002-9343(65)90015-x.

41. McMillan B, Kelly A, Walker JC. Prevalence of Hymenolepis diminuta infection in man in the New Guinea highlands. Trop Geogr Med 1971;23(4):390-2.

42. Cohen R, Mackey K. Hymenolepis diminuta unresponsive to quinacrine. West J Med 1977;127(4):340-1.

43. Kan SK, Kok RT, Marto S, Thomas I, Teo WW. The first report in Hymenolepis diminuta infection in Sabah, Malaysia. Trans R Soc Trop Med Hyg 1981;75(4):609. doi: 10.1016/0035-9203(81)90219-4.

44. Pampiglione S, Visconti S, Pezzino G. Human intestinal parasites in Subsaharan Africa. II. Sao Tomé and Principe. Parassitologia 1987;29(1):15-25.

45. Levi MH, Raucher BG, Teicher E, Sheehan DJ, McKitrick JC. Hymenolepis diminuta: one of three enteric pathogens isolated from a child. Diagn Microbiol Infect Dis 1987;7(4):255-9. doi: 10.1016/0732-8893(87)90140-4

46. Hamrick HJ, Bowdre JH, Church SM. Rat tapeworm (Hymenolepis diminuta) infection in a child. Pediatr Infect Dis J 1990;9(3):216-9. doi: 10.1097/00006454-199003000-00016.

47. Tena D, Pérez Simón M, Gimeno C, Pérez Pomata MT, Illescas S, Amondarain I, et al. Human infection with Hymenolepis diminuta: case report from Spain. J Clin Microbiol 1998;36(8):2375-6.
48. Marangi M, Zechini B, Fileti A, Quaranta G, Aceti A. Hymenolepis diminuta infection in a child living in the urban area of Rome, Italy. J Clin Microbiol 2003;41(8):3994-5. doi: 10.1128/jcm.41.8.3994-3995.2003.

49. Watwe $S$, Dardi CK. Hymenolepis diminuta in a child from rural area. Indian J Pathol Microbiol 2008;51(1):149-50. doi: 10.4103/0377-4929.40431.

50. Patamia I, Cappello E, Castellano-Chiodo D, Greco F, Nigro L, Cacopardo B. A human case of Hymenolepis diminuta in a child from eastern Sicily. Korean J Parasitol 2010;48(2):167-9. doi: 10.3347/kjp.2010.48.2.167.

51. Rohela M, Ngui R, Lim YA, Kalaichelvan B, Wan Hafiz WI, Mohd Redzuan AN. A case report of Hymenolepis diminuta infection in a Malaysian child. Trop Biomed 2012;29(2):224-30.

52. Karuna T, Khadanga S. A case of Hymenolepis diminuta in a young male from Odisha. Trop Parasitol 2013;3(2):145-7. doi: 10.4103/2229-5070.122145 .

53. Kołodziej P, Rzymowska J, Stępień-Rukasz H, Lorencowicz R, Lucińska M, Dzióbek M. Analysis of a child infected with Hymenolepis diminuta in Poland. Ann Agric Environ Med 2014;21(3):510-1. doi: 10.5604/12321966.1120592.

54. Tiwari S, Karuna T, Rautaraya B. Hymenolepis diminuta Infection in a Child from a Rural Area: A Rare Case Report. J Lab Physicians 2014;6(1):58-9. doi: 10.4103/0974-2727.129096.

55. Mane P, Sangwan J. Hymenolepis diminuta infection in a young boy from rural part of Northern India. J Family Med Prim Care 2016;5(1):166-7. doi: 10.4103/2249-4863.184655.

56. Ahmad AF, Ngui R, Ong J, Sarip F, Ismail WHW, Omar H, et al. Case Report: A Symptomatic Case of Hymenolepis diminuta Infection in an Urban-Dwelling Adult in Malaysia. Am J Trop Med Hyg 2017;97(1):163-5. doi: 10.4269/ajtmh.15-0877.

57. Sharifdini M, Hajialilo E, Ghanbarzadeh L, Saraei M. Infection with Hymenolepis diminuta (Rodolphi, 1819) in a Child from North of Iran: Case Report. Iran J Public Health 2019;48(8):1528-31.

58. Pisash KS. Cestodes. J Med Assoc Thai 1935;18:293-309.

59. Chandler AC. The distribution of $H$. diminuta infection in India and discussion of its epidemiological significance. Indian J Med Res 1927;14:973.

60. Szeja N. Entomofagia - aspekty żywieniowe i psychologiczne. Kosmos 2019;68(3):489-501.

61. Motakef M. Report of a case infected with Hymenolepis diminuta in Mashad. J Mashad School Med 1968;10:472-74.

62. Ghadirian E, Arfaa F. Human infection with Hymenolepis diminuta in villages of Minab, southern Iran. Int J Parasitol 1972;2(4):481-2. doi: 10.1016/0020-7519(72)90093-8.

63. Plonka W. Cestode infections in Poland in 1994. Prz Epidemiol 1996;50:199-203.

64. Plonka W. Cestode infections in Poland in 1997. Prz Epidemiol 1999;53:159-65.

65. Waloch M. Cestode infections in Poland in 2001. Prz Epidemiol 2003;57:159-63.

66. Waloch M. Cestode infections in Poland in 2002. Prz Epidemiol 2004;58:165-9.

67. Waloch M. Cestode infections in Poland in 2009. Prz Epidemiol 2011;65:285-8.

68. Kapczuk P, Kosik-Bogacka D, Łanocha-Arendarczyk N, Gutowska I, Kupnicka P, Chlubek D, et al. Selected Molecular Mechanisms Involved in the Parasite - Host System Hymenolepis diminuta - Rattus norvegicus. Int J Mol Sci 2018;19(8):2435. doi: 10.3390/ijms19082435.

69. McKay DM, Halton DW, McCaigue MD, Johnston CF, Fairweather I, Shaw C. Hymenolepis diminuta: intestinal goblet cell response to infection in male C57 mice. Exp Parasitol 1990;71(1):9-20. doi: 10.1016/0014-4894(90)90003-i.

70. Steinmann P, Cringoli G, Bruschi F, Matthys B, Lohourignon LK, Castagna B, et al. FLOTAC for the diagnosis of Hymenolepis spp. infection: proof-of-concept and comparing diagnostic accuracy with other methods. Parasitol Res 2012;111(2):749-54. doi: 10.1007/s00436-012-2895-9.

71. Brindley PJ, Sher A. Immunological involvement in the efficacy of praziquantel. Exp Parasitol 1990;71(2):245-8. doi: 10.1016/00144894(90)90028-b. 